\title{
SELF-EXCITED VibRATION OF INK ROLLERS
}

\author{
Martin Pustka ${ }^{1}$; Pavel Šidlof ${ }^{2}$ \\ VÚTS, a.s., Measurement Department, \\ Svárovská 619, Liberec XI - Růžodol I, 46001 Liberec, Czech Republic \\ e-mail: ${ }^{1}$ martin.pustka@vuts.cz; ${ }^{2}$ pavel.sidlof@vuts.cz
}

\begin{abstract}
A vibration having a character of self-excited chatter oscillation known from machine tools is observed during intermittent motion of ink rollers of offset printing machines. This vibration occurs under specific operating conditions and is often accompanied by an increased noise level. To explain this unusual vibration behavior, a simple analytical model of two rollers interaction is derived. The calculated oscillation is compared with the measurement of ductor roller displacement. The model results confirm the possibility of self-excited vibration development in the presence of viscous forces, negative damping effects and continuous supply of external energy from roller rotation.
\end{abstract}

\section{Keywords}

Self-excited oscillation; Viscous friction force; Negative damping; Offset printing machine.

\section{Introduction}

Offset printing is widely used and currently the most important printing technology. The continuous development and automation of offset printing machines provide increased productivity and higher media quality. However, the requirements for higher production speed also increase the dynamic loading of mechanisms, often accompanied by a significant noise and a vibration emission.

The inking unit of offset printing machine transfers the ink from the ink fountain to the plate cylinder [1]. To have a thin, uniform film of ink, the inking unit is composed of a system of many (ten or more) rollers. The quantity of ink supplied to the inking process is determined by the adjustment and the speed of the input part shown in Fig. 1.

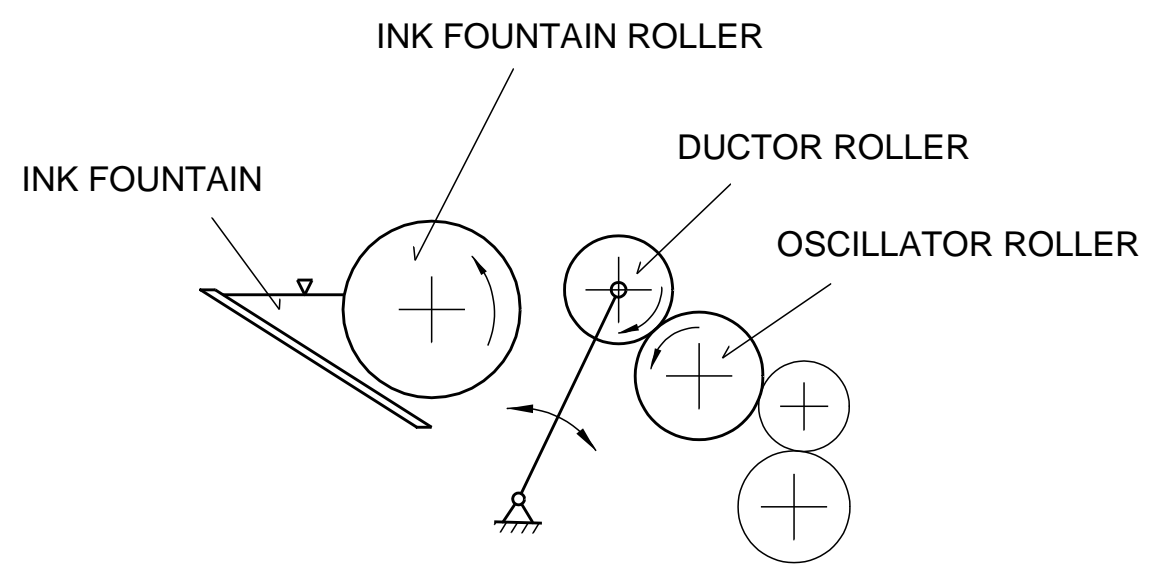

Source: Own

Fig. 1: Scheme of the input part of inking unit 
The ink fountain roller and the oscillator roller (including ductor roller tipping mechanism) are driven independently and the rollers have substantially different circumferential velocities. The ductor roller rotates freely and is alternately in contact with the fountain roller and with the oscillator roller to transfer a specified amount of ink. At the moment of contact, the ductor roller abruptly changes its rotational speed.

At high production speeds, the roller impacts are associated with an increased noise and a vibration of the ductor roller. These effects occur only under specific operating conditions, i.e. for rollers covered by an ink layer and at a certain interval of rotational speed. The vibration waveform indicates the potential occurrence of a self-excited oscillation.

\section{$1 \quad$ Research Objectives}

The self-induced vibration of ink rollers is an interesting and rather unusual phenomenon. The aim of the research is an initial study of the causes and sources of this vibration behavior including positive and negative damping effects. A simplified analytical model of the roller interaction is created to approximately simulate the measured roller vibration.

\section{$2 \quad$ Vibration of Ductor Roller}

An example of a trajectory of ductor axis center point in a plane perpendicular to this axis within one cycle of a reciprocal motion between an ink fountain and an oscillator roller is depicted in Fig. 2. The deflection of the axis center point is derived from the displacement of the ductor surface measured by means of two laser triangulation sensors in the middle of the ductor length. This trajectory is not exactly the same in individual cycles due to a high sensitivity to initial and boundary conditions.

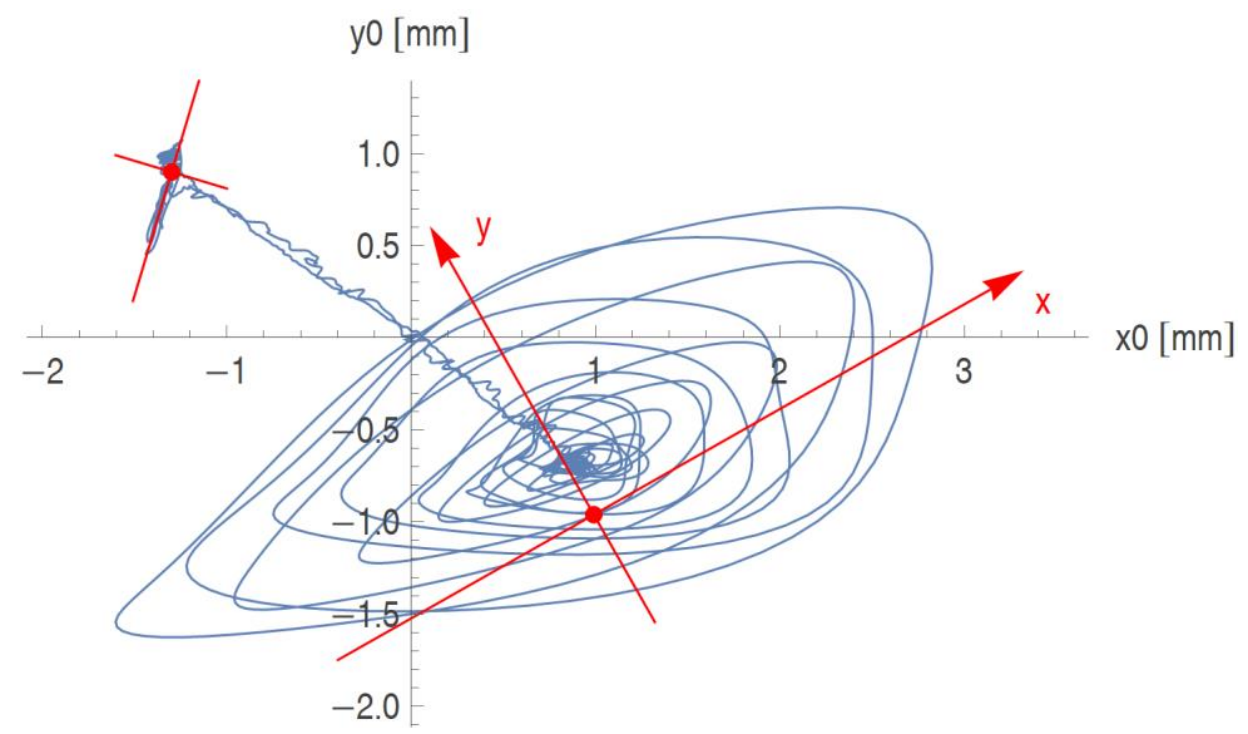

Source: Own

Fig. 2: Plane motion of ductor axis center point (one cycle of the reciprocal motion between ink fountain and oscillator roller), red-tangent and normal lines to the adjacent rollers at a steady rolling

An excessive vibration of ductor axis center point (a bending deflection) is clearly seen in both reversal points, particularly at the contact with the oscillator roller. The detail of axis center point displacement (in the direction $x$ of the tangent to the oscillator) and the corresponding sound pressure at the impact on the oscillator are shown in Fig. 3. The measurement microphone was located near the roller surface. 


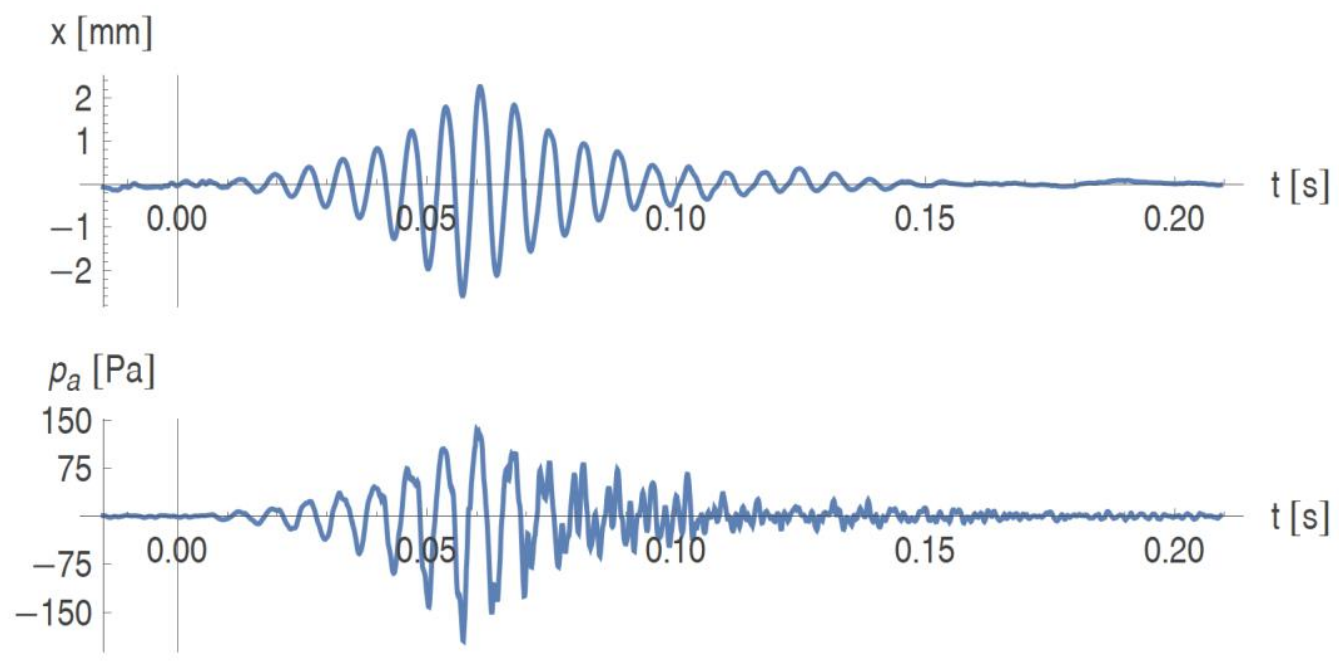

Source: Own

Fig. 3: The oscillating deflection of ductor axis center point (top) and sound pressure near ductor roller (bottom) at the moment of the impact on the oscillator roller

The vibration behavior shown in Fig. 3 is apparently non-linear. After the contact of roller ink layers (approximately at a time of $0 \mathrm{~s}$ ) the vibration amplitudes start to increase gradually with a frequency of ductor fundamental bending mode. This behavior is similar to the self-excited chatter vibrations of machine tools [2] or of other mechanical or fluid systems [3]. The selfexcited vibrations are generally characterized by a negative damping, a positive feedback and an energy import from an external source.

After a certain time (approximately at $0.06 \mathrm{~s}$ ) the vibration amplitudes rapidly reduce, which corresponds to a common characteristic of a damped mechanical system with positive damping. To explain this vibration behavior, a simplified model of the roller interaction is derived in the next chapter.

\section{$3 \quad$ Research Methods}

\subsection{Model of Roller Vibration}

The transient vibration of the ductor roller during the contact of the ductor and the oscillator is modelled using the analytical model depicted in Fig. 4. The model is based on a simplified kinematic geometry of a real system and on a number of other simplifying assumptions. The ductor roller is substituted by a cylindrical disc of mass $m$ and moment of inertia $J$. The disc axis is flexibly mounted in the horizontal direction $x$, oscillations in the vertical direction are neglected. The values of stiffness $k$ and viscous damping coefficient $b$ correspond to the eigenfrequency and modal damping of the roller fundamental bending mode [4].

The vertical displacement of the disc is defined by a cam mechanism lift $y$ shown in Fig. 5. In the end position the rollers are compressed and deformed (the ductor has a rubber surface) and the contact area between rollers (a roller nip) is $S=p_{0} l$, where $p_{0}$ is the static nip width and $l$ is the disc length. Both rollers have the same ink layer of thickness $h$ and at the moment of impact $t=0$ they are separated by a gap of height $2 h$. We suppose that the ink (which is thixotropic in fact) exhibits the Newtonian flow characteristics [5] and has a constant dynamic viscosity $\eta$.

Before the impact, the oscillator rotates with a constant angular velocity $\omega_{0}$ and the angular velocity $\omega$ of the disc is zero. At the contact of ink layers (time $0 \mathrm{~s}$ in Fig. 5) the viscous 
friction force $F$ is developed, which spins the model disc with the increasing velocity $\omega$ and simultaneously excites the vibration in the horizontal direction. The force $F$ is proportional to the velocity gradient of ink layer and to the momentary nip width $p$.

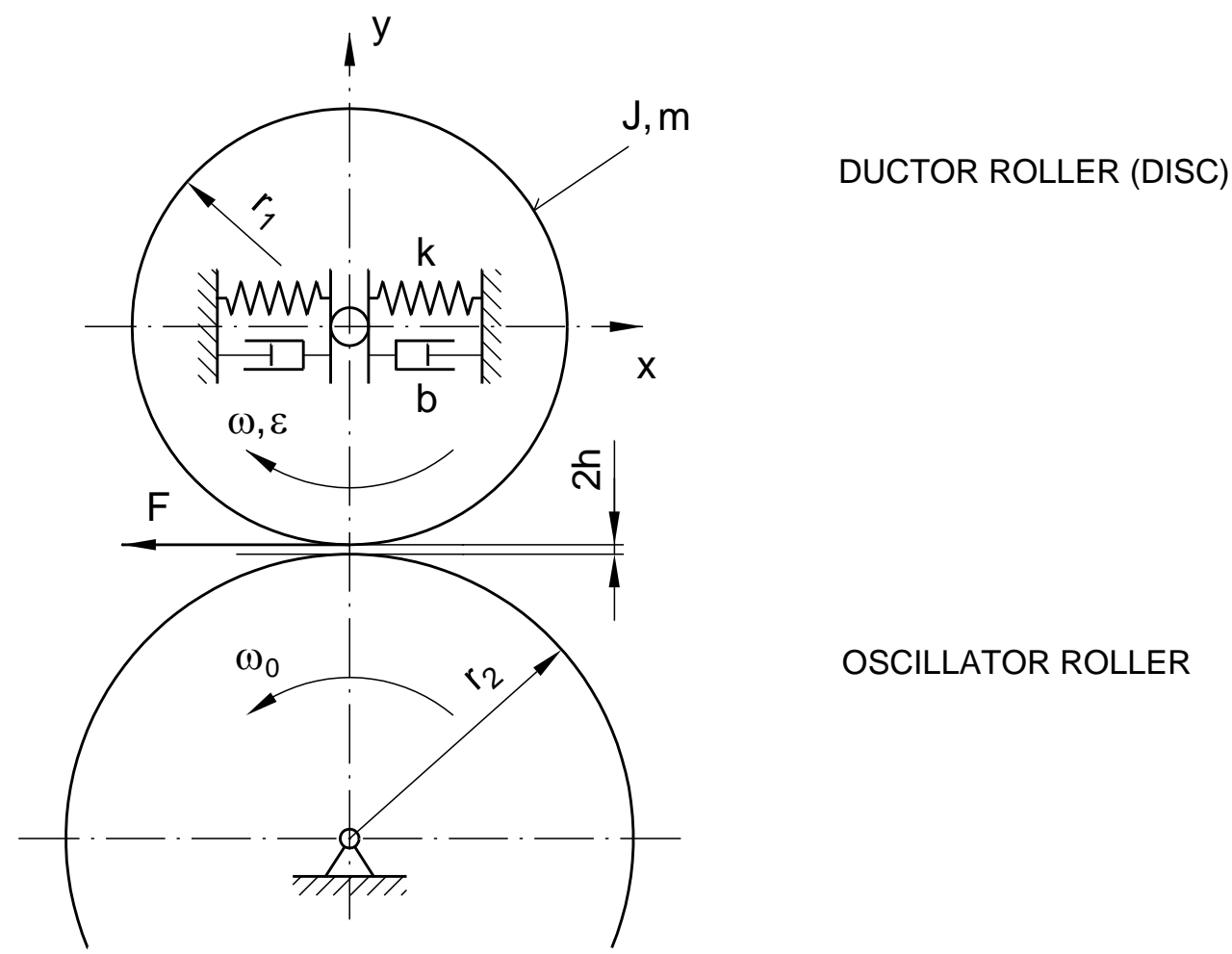

Source: Own

Fig. 4: Model of ductor roller transient vibration at the roller contact

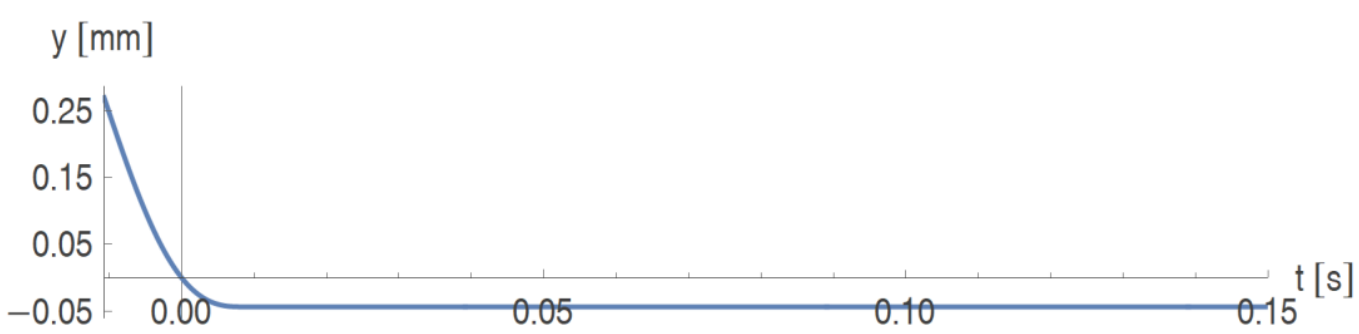

Source: Own

Fig. 5: Cam lift $y(t)$

\subsection{Equations of Motion}

The governing equations of motion have a form

$$
\begin{gathered}
m \ddot{x}(t)+b \dot{x}(t)+k x(t)-\frac{J}{r_{1}} \dot{\omega}(t)=0, \\
\frac{J}{r_{1}} \dot{\omega}(t)-\left(r_{2} \omega_{0}-r_{1} \omega(t)+b_{s}(t) \dot{x}(t)\right) \frac{1}{2 h} \eta p(t) l=0,
\end{gathered}
$$

where $r_{1}, r_{2}$ are ductor and oscillator diameters. The momentary nip width $p$ satisfies a simplified geometrical condition

$$
p(t)=\sqrt{-4 r_{s} y(t)-y^{2}(t)-x^{2}(t)} \text { for } y(t)<0 \text { and } x^{2}(t)>4 r_{s} y(t)+y^{2}(t),
$$




$$
p(t)=0 \text { elsewhere }
$$

where $r_{s}=\frac{r_{1}+r_{2}}{2}$ is the mean rollers radius.

The variable damping necessary for the self-excited vibration followed by the damped vibration (as discussed in Introduction) is modelled by the damping function $b_{s}$, which is introduced into Eq. (2) for the viscous friction force. The function $b_{s}$ shown in Fig. 6 was created artificially using arctangent function to correspond to the measured time history in Fig. 3.

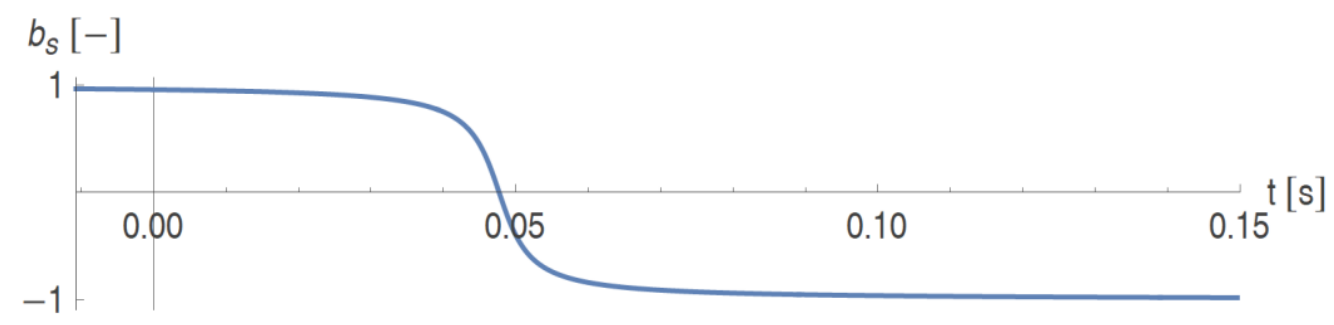

Source: Own

Fig. 6: Damping function $b_{s}(t)$

The model of roller vibration has two degrees of freedom, namely the horizontal displacement of ductor axis $x$ and the ductor angular velocity $\omega$. The resulting time courses can be obtained by a simultaneous solution of Eqs. (1) and (2) with initial conditions $x(0)=0$ and $\omega(0)=0$.

\section{$4 \quad$ Calculation Results}

The model parameters used for calculation are given in Table 1. These numeric values correspond to the dimensions and parameters of a large-format sheetfed offset press.

Tab. 1: Calculation parameters

Source: Own

\begin{tabular}{|l|c|}
\hline effective mass $m[\mathrm{~kg}]$ & 8.0 \\
\hline moment of inertia $J\left[\mathrm{~kg} \cdot \mathrm{m}^{2}\right]$ & 0.0283 \\
\hline effective stiffness $k[\mathrm{~N} / \mathrm{m}]$ & $6.8 \cdot 10^{6}$ \\
\hline viscous damping coefficient $(\xi=3 \%) b\left[\mathrm{Nms}^{-1}\right]$ & 440 \\
\hline ductor diameter $r_{1}[\mathrm{~m}]$ & 0.059 \\
\hline oscillator diameter $r_{2}[\mathrm{~m}]$ & 0.076 \\
\hline effective disc length $l[\mathrm{~m}]$ & 0.35 \\
\hline static nip width $p_{0}[\mathrm{~m}]$ & 0.003 \\
\hline ink thickness $h[\mathrm{~m}]$ & $10^{-5}$ \\
\hline ink viscosity $\eta[\mathrm{Pa} . \mathrm{s}]$ & 10 \\
\hline oscillator angular velocity $\omega_{0}[\mathrm{rad} / \mathrm{s}]$ & 78 \\
\hline
\end{tabular}

The calculated time courses of ductor axis displacement $x$, angular velocity $\omega$, difference velocity $\Delta v$ and viscous force $F$ are depicted in Fig. 7. The difference of the oscillator and the ductor circumferential velocity $\Delta v$ is obtained from 


$$
\Delta v(t)=r_{2} \omega_{0}-r_{1} \omega(t)
$$

the tangential viscous force $F$ between rollers is given by

$$
F(t)=\frac{J}{r_{1}} \dot{\omega}(t)
$$
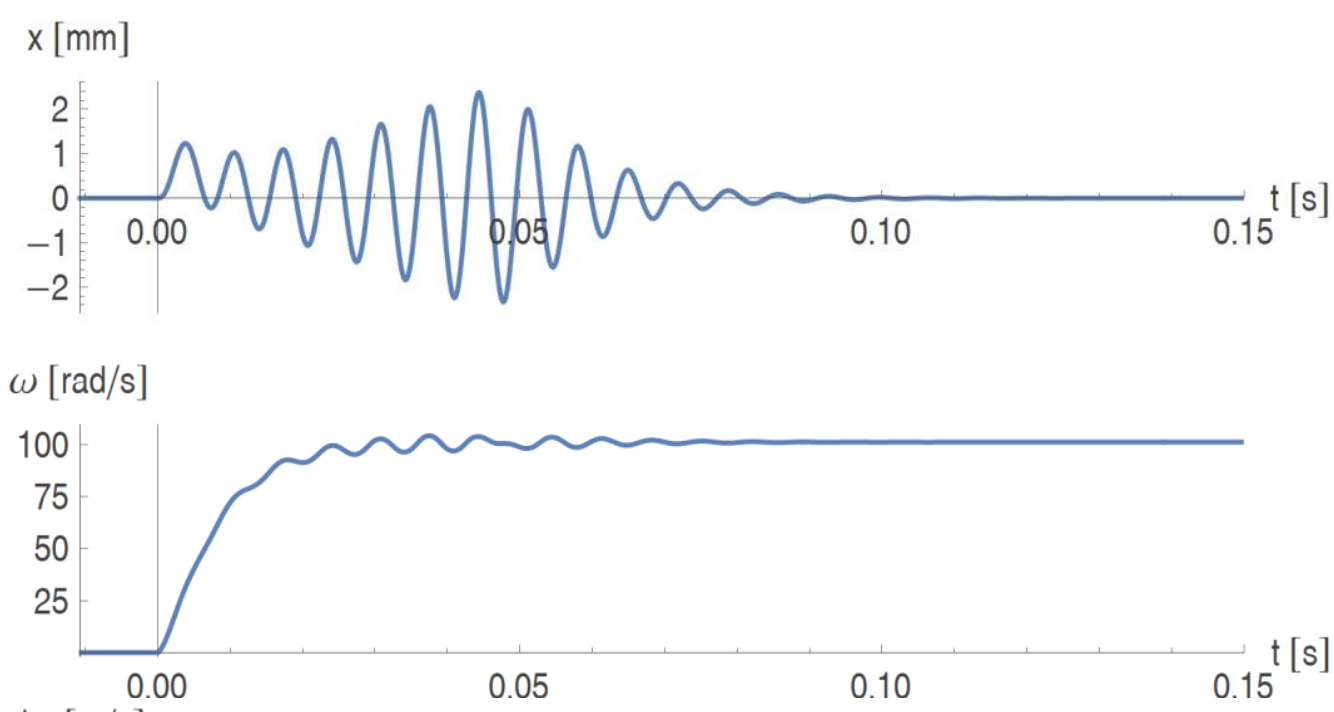

$\Delta \mathrm{v}[\mathrm{m} / \mathrm{s}]$
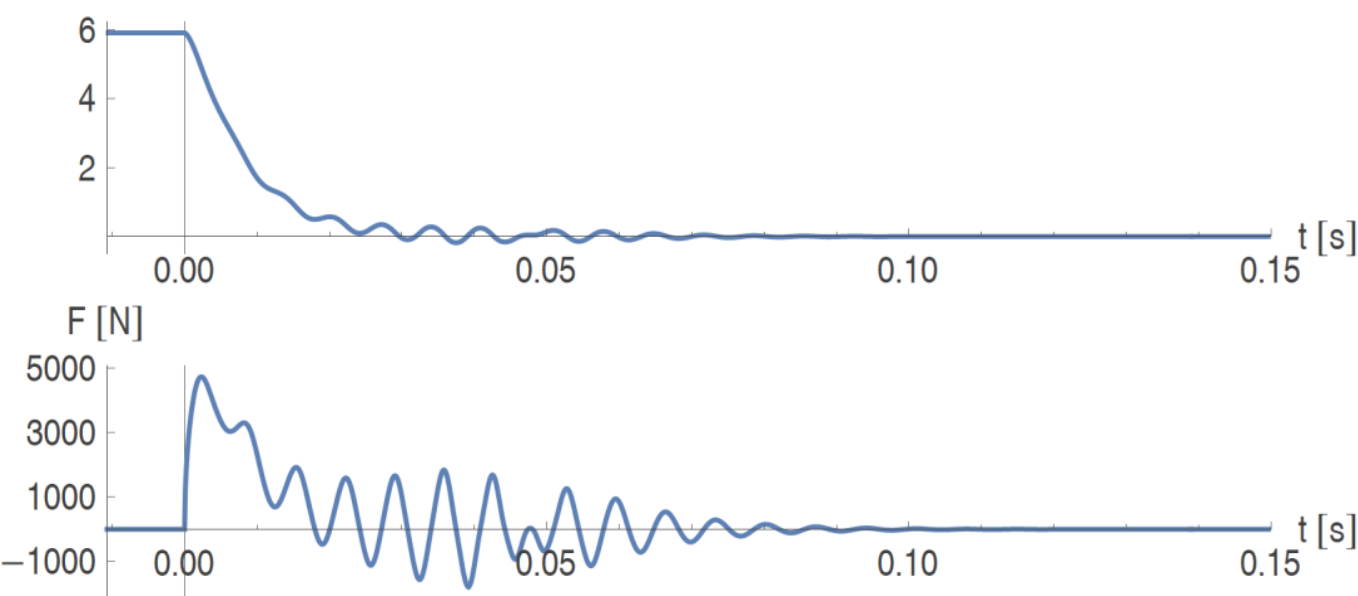

Source: Own

Fig. 7: Calculated time courses of (top to bottom) ductor disc axis horizontal displacement $x(t)$, angular velocity $\omega(t)$, difference circumferential velocity $\Delta v(t)$ and tangential viscous force $F(t)$

The time mark at $0 \mathrm{~s}$ in Fig. 7 indicates the contact of ink layers (see also Fig. 5). The time course of the axis horizontal displacement $x$ corresponds relatively well to the measured history shown in Fig. 3. The most crucial is the difference of displacement and force amplitudes at the beginning, which is the result of a sudden development of the viscous force $F$ at the rollers contact. The model assumes a constant value of dynamic viscosity $\eta$ and a constant velocity gradient. However, the local ink viscosity at the contact surface abruptly decreases due to the heating of a small amount of ink caused by friction. With a gradual increase of ductor speed increases also the flow of adhered ink and the ink heating and viscosity decrease are reduced. The force amplitude increases in fact gradually from zero. 
The effect of variable damping is clearly visible in Fig. 7. After a stabilization of the angular velocity $\omega$ the increasing vibration is suppressed, and the vibration amplitudes rapidly reduce. From this we can conclude that at the beginning the ductor vibration is evidently self-excited with the rotating oscillator roller being an external energy source. When the difference circumferential velocity $\Delta v$ significantly decreases, the external energy disappears, and the damping of the system becomes positive.

\section{Conclusion}

An interesting phenomenon of a vibration similar to a self-excited chatter oscillation was recently observed on printing machines during an intermittent motion of ink rollers. The excessive vibration of ductor roller occurs only in the presence of ink layer at a certain interval of rotational speed and is accompanied by a high noise level.

To clarify the origin of this vibration under quite complicated conditions, a simplified analytical model of rollers contact was created. The model results indicate a probable source of the vibration behavior, which is a viscous friction force originating in the ink layer between rollers. In the presence of an energy import caused by different circumferential velocities of both rollers the ink layer interaction creates a positive feedback, which excites the selfoscillation of the ductor roller. The excitation effect of the viscous force rapidly disappears after the velocity difference significantly decreases.

The simplified model describes this vibration problem only approximately and the process of roller self-excitation should be further analyzed, e.g., by means of advanced modelling using FEM and computational fluid dynamics methods.

\section{Acknowledgements}

This work was supported by the Czech Ministry of Industry and Trade in the framework of the institutional support for long-term conceptual development of research organization whose recipient was VÚTS, a.s.

\section{Literature}

[1] KIPPHAN, H. (ed.): Handbook of Print Media: Technologies and Production Methods. Springer-Verlag Berlin Heidelberg, 2001. ISBN 978-3-540-67326-2. eBook ISBN 9783-540-29900-4. DOI: 10.1007/978-3-540-29900-4

[2] QUINTANA, G.; CIURANA, J.: Chatter in machining processes: A review. International Journal of Machine Tools and Manufacture. 2011, Vol. 51, Issue 5, pp. 363-376. DOI: 10.1016/j.ijmachtools.2011.01.001

[3] TONDL, A.: To the problem of self-excited vibration suppression. Engineering Mechanics. 2008, Vol. 15, Issue 4, pp. 297-307. Available from WWW: http://www.engineeringmechanics.cz/pdf/15_4_297.pdf

[4] BREPTA, R.; PU゚ST, L.; TUREK, F.: Mechanické kmitání. Sobotáles, Praha, 1994. ISBN-13 978-80-901684-8-0. ISBN 80-901684-8-5.

[5] CHHABRA, R. P.: Non-Newtonian Fluids: An Introduction. In: Krishnan J.; Deshpande A.; Kumar P. (eds), Rheology of Complex Fluids. Springer, New York, NY, 2010, pp. 3-34. ISBN 978-1-4419-6493-9. Online ISBN 978-1-4419-6494-6. DOI: $\underline{10.1007 / 978-1-4419-6494-6 \_1}$

doc. Ing. Martin Pustka, Ph.D.; Ing. Pavel Šidlof, CSc. 


\section{SAMOBUZENÉ KMITÁNÍ BARVICÍCH VÁLCŮ}

Při stř́ídavém pohybu barvicích válců tiskového stroje se vyskytují vibrace mající charakter samobuzených kmitů, které jsou známy například u obráběcích strojů. Tyto vibrace vznikají při určitých provozních podmínkách a jsou často doprovázeny zvýšenou hladinou hluku. Pro objasnění tohoto neobvyklého kmitavého chování je odvozen jednoduchý analytický model vzájemného působení dvou válců. Vypočtené vibrace jsou porovnány s měřením posunutí barvicího válce. Výsledky modelování potvrzují možnost vyvolání samobuzených kmitů při přítomnosti viskózních sil, účinků záporného tlumení a přívodu vnější energie tvořené otáčením válce.

\section{SELBSTERREGTE SCHWINGUNG DER FARBWALZEN}

Bei der intermittierenden Bewegung der Farbwalzen tritt eine Schwingung auf, die den Charakter einer selbsterzeugten Schwingung hat und die aus dem Bereich der Werkzeugmaschinen bekannt ist. Diese Schwingung entsteht unter bestimmten Betriebsbedingungen und wird oft von Geräuschemission begleitet. Für die Erklärung dieses ungewöhnlichen Schwingverhaltens wird das einfache analytische Modell der Zwei-WalzenGegenwirkung entworfen. Die berechnete Schwingung wird mit der Messung des Wegs von Farbwalzen verglichen. Die Modellergebnisse bestätigen die Möglichkeit, eine selbsterzeugte Schwingung in Gegenwart von Viskoskräften, von Wirkungen negativer Dämpfung und der Zuführung der äußeren Energie der Walzendrehung zu erzeugen.

\section{DRGANIA SAMOWZBUDNE WAŁKÓW FARBOWYCH}

Podczas przemiennego ruchu wałków farbowych maszyny drukarskiej występują drgania mające charakter drgań samowzbudnych, które występują przykładowo w maszynach do obróbki. Drgania te powstają w pewnych warunkach eksploatacyjnych i często towarzyszy im wyższy poziom hałasu. Dla wyjaśnienia tych nietypowych drgań opracowano prosty model analityczny wzajemnego oddziaływania dwóch wałków. Obliczone drgania porównano z pomiarami przesunięć wałka farbowego. Wyniki modelowania potwierdzają możliwość wywołania drgań samowzbudnych w obecności oporu wiskotycznego, oddziaływania oporu ujemnego i wpływu energii zewnętrznej generowanej przez obroty wałka. 